\title{
Assessment of toxicity in fresh water fish Labeo rohita treated with silver nanoparticles
}

\author{
Muhammad Saleem Khan ${ }^{1}$ - Naureen Aziz Qureshi ${ }^{2}$. Farhat Jabeen ${ }^{1}$
}

Received: 19 February 2017/ Accepted: 28 March 2017/Published online: 5 April 2017

(C) The Author(s) 2017. This article is an open access publication

\begin{abstract}
Silver nanoparticles $(17.78 \pm 12.12 \mathrm{~nm})$ were synthesized by the reduction of $0.5 \mathrm{M}$ silver nitrate using formaldehyde as reducing and triethylamine as promoting and stabilizing agent. The particles were grain like agglomerates with spherical, centered-face cubic and crystalline in nature. The sample was highly pure with amine (NH) as associated and capping molecules. Further, the genotoxicity and oxidative stress of these particles were evaluated using Labeo rohita (L. rohita) as genetic model exposed (10-55 $\mathrm{mg} \mathrm{L}^{-1}$ dose) through aquatic medium for 28 days. The cells were produced with micronuclei, fragmented, lobed and buds nuclei in dose dependent manner. The highest incidence of comet was recoded $(27.34 \pm 5.68)$ at $55 \mathrm{mg} \mathrm{L}^{-1} \mathrm{Ag}$-NPs and 14 days treatment. Then frequency was decreased to $22.65 \pm 6.66 \%$ after 28 days due to complex repair mechanism. Moreover, the treatment also produces the oxidative stress and disturbs the level of GST in gill and liver tissue. There was a sharp decline in the activities of GST and this decrease of activity increase the MDA content. Further, the elevated level of GSH represents that the liver has started defensive mechanism against oxyraidcals. This study concluded, Ag-NPs are genotoxic in nature and produce micronuclei, comet cells and also induces oxidative stress in aquatic organisms.
\end{abstract}

Keywords Nanoparticle - Silver - Synthesis · Genotoxicity $\cdot$ Comet $\cdot$ Micronuclei

Muhammad Saleem Khan samiikhan@yahoo.com

1 Department of Zoology, Government College University Faisalabad, Faisalabad, Pakistan

2 Department of Zoology, Government College Women University Faisalabad, Faisalabad, Pakistan

\section{Introduction}

The nanoparticles are extensively synthesized with an average of 60,000 tons annual production (Jovanović et al. 2011). The 622 companies of 30 countries produce 1814 nanoproducts of various application (Woodrow Wilson 2016). Only 435 nanoproducts are silver based, forming $34 \%$ of total with 320 tons annual production (Jovanović et al. 2011; Vance et al. 2015; Woodrow Wilson 2016). The extensive applications of Ag-NPs demand synthesis of these particles on large scale in economic ways. In the present decades, these particles are being synthesized through chemical, physical and biological methods. Among these, chemical reduction is more suitable method due to less cost of chemical, ease of control and less byproducts (Iravani et al. 2014). Silver nitrate is the most dominant procure compound to synthesized Ag-NPs. Various inorganic and organic reducing agent are utilized in the reduction, including sodium borohydrate, sodium citrate, ascorbate, Tollen's reagent, ethylene glycol, elemental hydrogen, and dimethyl formamide (Iravani et al. 2014; Tran and Le 2013). Currently, formaldehyde was used as reducing agent and triethylamine performed dual function as promoting and stabilizing agent.

The extensive use of $\mathrm{Ag}$ nanoproducts increases the discharge into aquatic and terrestrial environment. It further contaminated the environment through cement manufacturing, weathering of rocks, burning of fusel fuel, processing of ores, leaching and anthropogenic activities (Awasthi et al. 2013; Benn and Westerhoff 2008; Taju et al. 2014). Rain is liable to release the silver in the water reservoirs or ground water (Wijnhoven et al. 2009). In the aquatic environment, it exits in four oxidation states $(\mathrm{Ag}$, $\mathrm{Ag}^{+}, \mathrm{Ag}^{+2}$ and $\mathrm{Ag}^{+3}$ ) with $\mathrm{Ag}$ and $\mathrm{Ag}^{+}$most common form (Levard et al. 2012; Smith and Carson 1977). Metallic

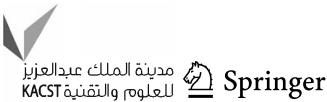


silver is insoluble, whereas salts $\left(\mathrm{AgCl}, \mathrm{AgNO}_{3}\right)$ are soluble in water and exists in the form of colloidal particles (Wijnhoven et al. 2009). Limit information regarding the toxicity of Ag-NPs particularly the genotoxicity and cytotoxicity is available (Khan et al. 2015a; Wijnhoven et al. 2009). Depending upon the literature, Ag-NPs are considered more toxic than other forms because of more readily absorbable. When it reaches the aquatic environment, AgNPs most likely to enter the ecosystems produce a physiological response and genotoxicity in animals (Luoma et al. 2008; Sohn et al. 2015). Further studies also revealed Ag-NPs cause the oxidative stress in the aquatic organisms (Devi et al. 2015; Khan et al. 2016). They increase the production of reactive oxygen species (ROS) and causes lipid peroxidation, intact with nucleic acid, lipid, protein, causes loss of membrane integrity, functional changes and mutation. All these factors contribute to health disorder (Kataria et al. 2010; Khan et al. 2015a, b). The other genotoxic effects include DNA double-strand breaks, DSBs, chromosomal aberrations such as acentric and dicentric chromosomes, chromosomal fragmentation and fusions in the treated organisms (Ahamed et al. 2008; AshaRani et al. 2008b; Igwilo et al. 2006; Khan et al. 2015a).

Numbers of toxicological studies have performed but it show huge variations due to lack of proper particles characterization (Gliga et al. 2014). In recent studies, the researchers have focused on toxicity of Ag-NPs in aquatic organisms (Khan et al. 2015a; Monfared and Soltani 2013; Rajkumar et al. 2015; Reddy et al. 2013; Taju et al. 2014). The L. rohita is widely consumed fish in Pakistan for its delicious taste. This fish occupy the major riverine system of country. Water pollution is the major issue in the rivers and ground water which badly affects the aquatic organisms. This fish has the ability to accumulate and concentrate the heavy metals above the surrounding environment (Hamid et al. 2016). Further, the test fish blood contained nucleated erythrocytes which further ease to estimate the damages due to environmental pollution. Therefore, this fish was used as model in the study.

\section{Materials and methods}

\section{Synthesis and characterization of Ag-NPs}

Silver nitrate $(99.9 \%)$, formaldehyde $(99 \%)$, triethylamine (98\%) was purchased from Merck (Germany) via local distributor. In the brief methodology, silver nitrate $\left(\mathrm{AgNO}_{3}\right)$ was used as precursor compound and triethylamine with few drops as promoting and stabilizing agent. The $0.5 \mathrm{M}$ solution of $\mathrm{AgNO}_{3}$ was prepared in the double deionized water in beaker and stirred for $30 \mathrm{~min}$ on a magnetic stirrer (ARE VELP) at room temperature and kept the beaker covered with aluminium foal to avoid contaminations. A few drops of triethylamine were added to the solution as reaction-promoting agent. The solution was stirred for $5 \mathrm{~min}$ and $5 \mathrm{ml}$ of formaldehydes added as reducing agent. The color of the solution started changing to black from clear, indicating the reduction of $\mathrm{AgNO}_{3}$ to Ag-NPs. After $5 \mathrm{~min}, 2 \mathrm{ml}$ of triethylamine was added as stabilizing agent. The solution was stirred for $2 \mathrm{~h}$ at room temperature and color was changed to greenish black. This solution was then stirred for $2 \mathrm{~h}$ at $160{ }^{\circ} \mathrm{C}$ on hot plate till particles precipitated out. The precipitates were then washed with deionized water, filtered, and washed again with ethanol followed by distilled water to remove the unbounded triethylamine. The filtered particles were dried in an incubator at $85^{\circ} \mathrm{C}$ overnight and grained in the piston mortal to fine powder form.

The synthesis of the particles was monitor through Hitachi U-2800 spectrophotometer $(5 \mathrm{~nm}$ resolution and wave lengths 200-700 $\mathrm{nm}$ ). The absorbance was recorded for the samples of $30 \mathrm{~min}, 2 \mathrm{~h}$ at room temperature and $2 \mathrm{~h}$ at $160{ }^{\circ} \mathrm{C}$ after mixing with formaldehyde. The morphology and size of particles was confirmed through SEM and TEM studies. The elemental composition was determined through EDX elemental analysis and associated molecules were recognized through FT-IR spectroscopy using Avatar Thermo Nicolet FT-IR spectrophotometer. The crystalline nature of the particles was confirmed through XRD analysis (thermo scientific ARL 100 X-ray diffractometer).

\section{Laboratory conditions, Ag-NPs treatments and samples collection}

The experimental L. rohita $(50 \pm 5 \mathrm{~g}$ weight, $29 \pm 09 \mathrm{~cm}$ in length) was purchased from the fish hatchery under the Punjab fishy department Faisalabad and maintained under separated aquarium (temperature $28 \pm 2{ }^{\circ} \mathrm{C}$ and 12:12 L: $\mathrm{D}$ period). The test aquaria contained 40 liters of water. After acclimatization of 2 weeks, the fishes were divided into seven groups of five fishes in each group. The first group served as control and other exposed to 10, 20, 30, 45 and $55 \mathrm{mg} \mathrm{L}^{-1} \mathrm{Ag}-\mathrm{NPs}$ for a period of 28 days. The fish was fed twice a day with artificial diet and blood samples were collected randomly after 14 and 28 days by cardiac puncture using 2-ml heparinized needle flushed with EDTA.

Liver and gill $(250 \mathrm{mg})$ were analyzed for silver concentrations. Using $3 \mathrm{ml}$ of concentrated nitric acid (Sigma Aldrich) all samples was digested (temperature $\sim 250{ }^{\circ} \mathrm{C}$; pressure $\sim 70$ bar) followed by addition of $3 \mathrm{ml}$ of concentrated hydrochloric acid (Plasma Pure Sigma Aldrich). The digested samples were further diluted with $2 \% \mathrm{v} / \mathrm{v}$ nitric acid to a final concentration of $8-12 \% \mathrm{v} / \mathrm{v}$. The limits 
of detection were between 0.7 and $2.0 \mathrm{ng} \mathrm{g}^{-1}$ in all samples.

\section{Micronucleus test}

A thin smear of blood from each treatment was made on pre-cleaned slide and fixed in methanol for $20 \mathrm{~min}$ after drying. The slides were air dried and stained with Giemsa staining $(6 \%)$ for $25 \mathrm{~min}$, washed with tap water, allowed to dried and examined at $100_{X}$ magnification under microscope (Nikon with DS-L3 camera). Small, circular or ovoid and non-refractive bodies with the same staining and focusing pattern as main nucleus was scored as micronuclei and frequency is each treatment was calculated with the following formula.

MN $(\%)=\frac{\text { Number of cells with micronuclei }}{\text { Total number of cells scored }} \times 1000$

The nuclear alterations (NA) were further identified as fragmented, notched, lobed and buds according to the classification proposed by Carrasco et al. (1990). Furthermore, unidentified NA were placed in others category.

\section{Comet assay}

Blood was diluted with PBS of equal volume. $100 \mu \mathrm{l}$ of $1 \%$ low melting point agarose (LMPA) was mixed and place $80 \mu \mathrm{l}$ of this mixture on prepared slides. To spread the gel, coverslips were placed on the slides and placed on ice bag for 5-10 min till the gel got hard. The coverslip was carefully removed and a third layer of $0.5 \% 80 \mu \mathrm{LPMA}$ was added to each slide. The coverslip was replaced again to evenly spread the gel. The slide was again placed in slides tray resting on the ice bags for 5-10 min till the gel was harden. Finally, the coverslips were removed and slides were placed in Coplin jar containing freshly prepared and chilled lysing solution, kept in dark and stored for $1 \mathrm{~h}$ in refrigerator.

The gel box was filled with freshly prepared buffer $(\mathrm{pH}$ 13) till all the slides were completely covered with buffers. The slides were kept for $20 \mathrm{~min}$ in the electrophoresis buffer. This allowed the unwinding of DNA and expresses the alkali-labile damage. The supply of power was turned on at 24 votes and adjusting the current at 300 milli-amperes. The slides were electrophoresed for $30 \mathrm{~min}$, gently removed from the buffer, placed in draining tray and coated with neutralizing solution drop by drop. The slides were allowed to dry, stained with ethidium bromide ( $80 \mu \mathrm{l})$ and leave for $5 \mathrm{~min}$. To remove the excess stain; the slides were dipped in the chilled distilled water.

The DNA damage was visualized using the fluorescence microscope (Nikon with DS-L3 camera). Generally, 100 cells were analyzed per sample for the migration of DNA fragments of nucleus. Three classes of comet were identified including class 1 (slightly damage), class 2 (moderate or medium damage) and class 3 (extensively damage) beside the normal cells depending upon the damage and tail migration. The frequencies of the classes were recorded through visual observations and tails were measured with CASP software. Data were represented in the frequency of comet against each concentration and tail migration was measured in micro meter $(\mu \mathrm{m})$.

\section{Oxidative stress analysis}

Gills and liver tissues were washed with ice cold $\mathrm{KCl}$ solution $(1.15 \%)$ blotted, weighted and then homogenized separately in ice cold 4 volume of homogenizing buffer $(1.15 \% \mathrm{KCl}$ and $50 \mathrm{nM}$ Tris- $\mathrm{HCl}$ to adjust the $\mathrm{pH}$ at 7.4). The tissues were homogenized with piston mortal and the content centrifuged at $10,000 \mathrm{rpm}$ for $20 \mathrm{~min}$ in centrifuge (Sigma 2-16 k). The supernatant was separated, decanted and used for the activities of selected enzymes with the following procedures.

The activity of GST was measured by the methodology of Habig et al. (1974) and expressed in mol/mg protein. The method formulated by Jollow et al. (1974) was used to determine the level of GSH expressed in $\mu \mathrm{mol} / \mathrm{mg}$ protein. The membrane lipid peroxidation was determined by estimating the level of MDA (Malonaldehyde content). The method of Wilchek and Bayer (1990) was used for estimation. The MDA content was calculated using the molar concentration coefficient $1.56 \times 10 \mathrm{M}^{-1} \mathrm{~cm}^{-1}$ expressed in $\mu \mathrm{mol} / \mathrm{mg}$ protein.

\section{Results}

\section{Characterization of particles}

A sharp characteristics peak of absorbance was recorded between 400 and $480 \mathrm{~nm}$ due to surface plasmon resonance of Ag-NPs absorption confirming the reduction of silver nitrate. The spectrophotometer showed stronger peak of absorbance taking the reading after $5 \mathrm{~min}, 2 \mathrm{~h}$ at room temperature and $2 \mathrm{~h}$ on $160{ }^{\circ} \mathrm{C}$ mixing with formaldehyde and continuous stirring (Fig. 1). The SEM image showed agglomerations of $17.78 \pm 12.12 \mathrm{~nm}$ grains like Ag-NPs. The histogram represents that maximum particles were between 5 and $20 \mathrm{~nm}$ ranges (Fig. 2). The high purity of the sample was confirmed due to sharp peaks of silver and without any impurity peak in the EDX spectrum. A sharp peak was recorded approximately between 3 and $4 \mathrm{keV}$ due to surface silver plasmon resonance (Fig. 3). Further, the particles were face-centered cubic and crystalline in 


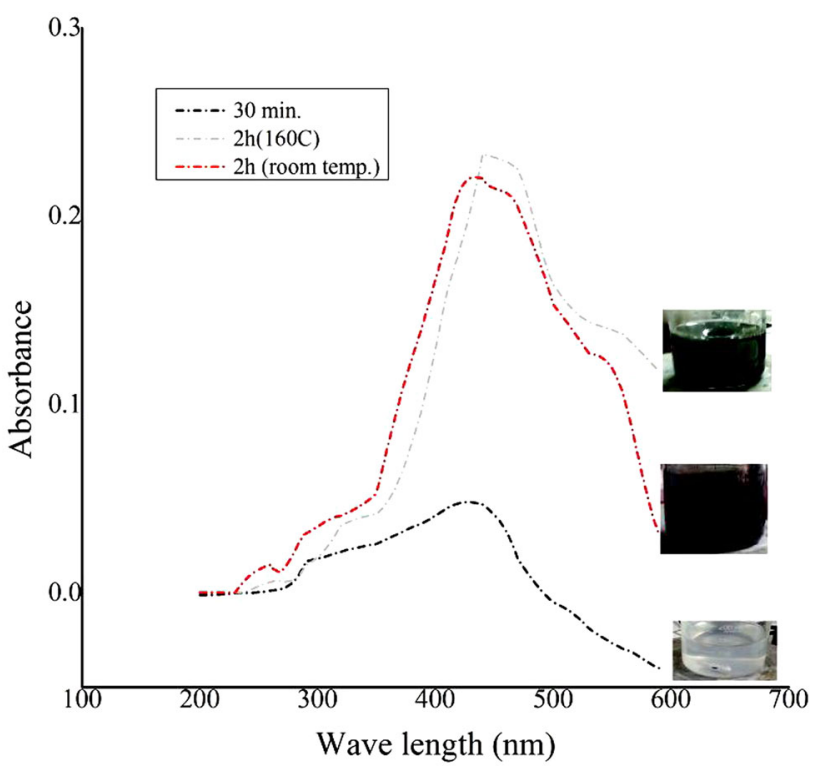

Fig. 1 UV-Vis absorption spectra of solution recorded after $30 \mathrm{~min}$, $2 \mathrm{~h}$ (room temp) and $2 \mathrm{~h}$ at $160{ }^{\circ} \mathrm{C}$ of mixing with reducing agent

nature confirmed through distinct peak approximately at $38.10 \theta$ (111), $44.30 \theta$ (200), $64.51 \theta$ (220) and $77.62 \theta$ (311) in the XRD analysis (Fig. 4). The structure parameters of Ag-NPs are provided in the Table 1.

The FT-IR spectroscopy conformed the capping and attach compounds to newly synthesized Ag-NPs. The prominent bands of absorption at $3334.7 \mathrm{~cm}^{-1}$ are characteristics for heterocyclic and amine $(\mathrm{NH})$ stretches. The bands at $2844.33 \mathrm{~cm}^{-1}$ represents methyl or methylene, $1654.35 \mathrm{~cm}^{-1}$ vibrations of amide, $1481.45 \mathrm{~cm}^{-1} \mathrm{NO}^{3-}$ and $1025.85 \mathrm{~cm}-1$ primary amide vibrations (Fig. 5). The TEM image of sol Ag-NPs presents varieties of shapes including spherical, triangular and irregular. The ring patterns of electron diffraction along the growth direction of Ag (110), (200), (220), (311) revealed the face-centered cubic and spherical crystalline nature of particles (Fig. 6).

Silver accumulation in the gill and liver tissues was time and dose dependent. Slightly higher amount of silver was found in the gill compared to liver possibly due to direct content with contaminated water. In control group, concentration was below the detection level (Fig. 7).

\section{Genotoxicity}

Mature and normal erythrocytes cells were large, oval and nucleated with 7-15 $\mu \mathrm{m}$ in size. Compare to control; significantly increase in the frequency of micronuclei recorded at each Ag-NPs treatment. Maximum frequency $(5.03 \pm 1.89)$ was recorded at $55 \mathrm{mg} \mathrm{L}^{-1}$ and 14 days treatment (Table 3) which continues to increase $6.31 \pm 2.63$ after 28 days (Table 4). However, at other concentrations the induction of MN gradually increased with the time of exposures. The other nuclear alterations were recognized as fragmented nuclei, lobed, notched, bud nuclei and unidentified designated as others (Fig. 8). All the Ag-NPs treatments show significantly different values of all classes compared to control group. Lobed nuclei were with the highest frequency $(3.64 \pm 0.50 \%)$ at $10 \mathrm{mg} \mathrm{L}^{-1}$ treatment after others $(3.52 \pm 1.71 \%)$ and fragmented nuclei $(1.973 \pm 0.62 \%)$. Notched nuclei were among the lowest in frequency after 14 days of treatment (Table 3).

The extant of genotoxicity was also evaluated through frequency of comet cells, DNA tail migration and comet class 1, 2, 3 (Figs. 9, 10). The highest incidence of comets was recoded $(27.34 \pm 5.68)$ at $55 \mathrm{mg} \mathrm{L}^{-1} \mathrm{Ag}$-NPs treatment. However, the frequency of comet was decreased to $22.65 \pm 6.66 \%$ after 28 days due repair mechanism. At low concentration, the frequency of class 1 was significantly higher than other classes. However, the frequency of other classes also increases with the increase of Ag-NPs concentration. Cells were severely damaged as represented by class 3 at $55 \mathrm{mg} \mathrm{L}^{-1}$ treatment and then decreased after 28 days due to repair mechanisms (Fig. 11).

The Ag-NPs also cause oxidative stress in the treated animals. A sharp decline in the activities of GST was found in both gills and liver tissue and this decrease in the GST activities were significantly different for each treatment.
Fig. 2 SEM image indicating the surface morphology and particle size histogram synthesized through reduction of silver nitrate
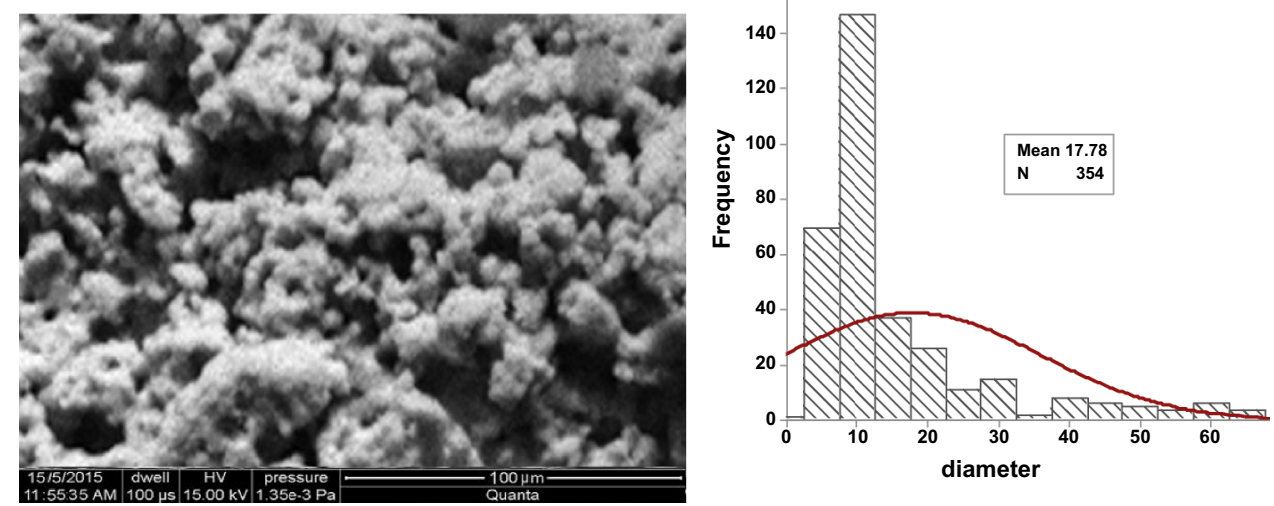


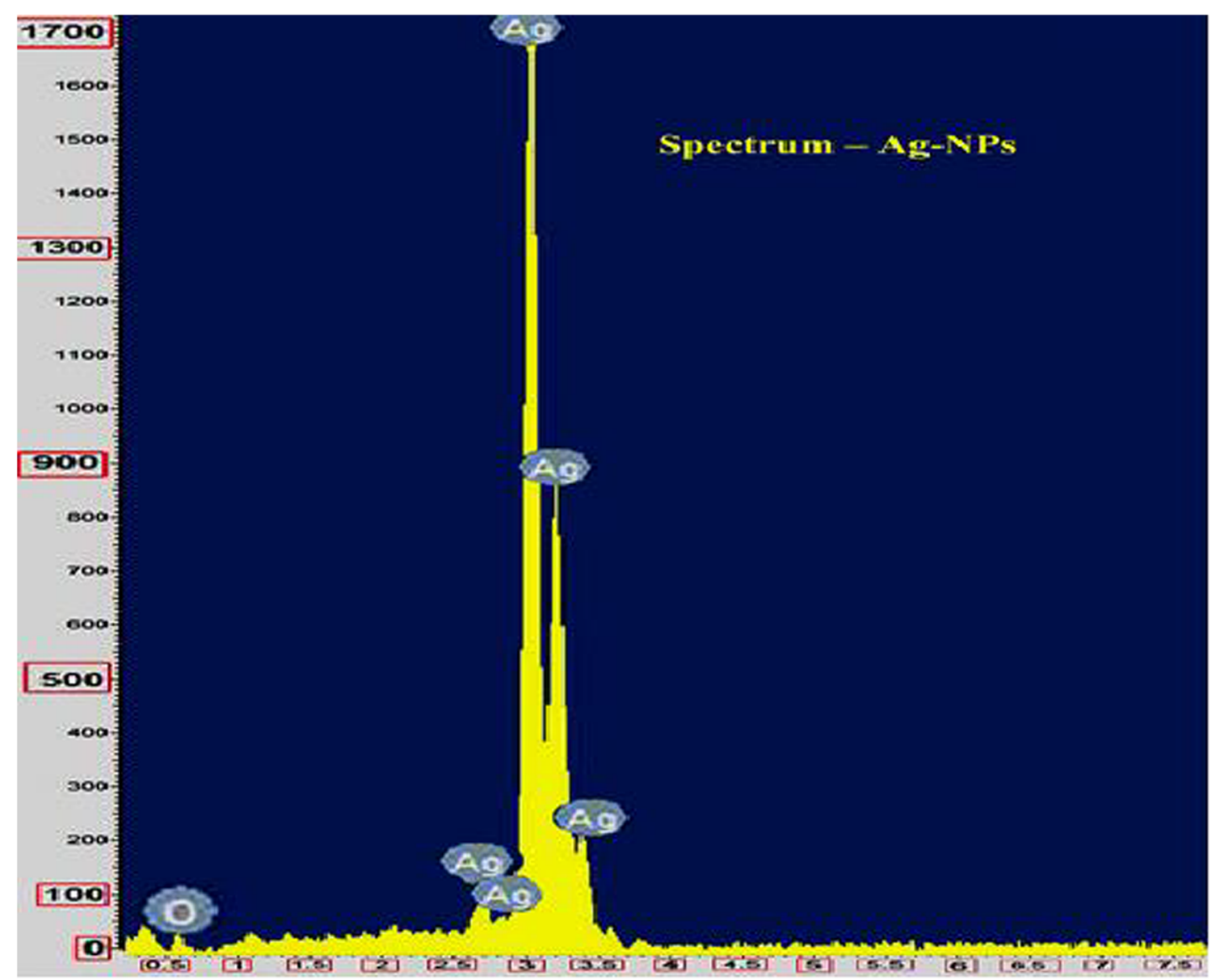

Fig. 3 EDX spectra recoded after Ag-NPs synthesis without any impurity peaks

Fig. 4 XRD diffraction spectra of Ag-NPs indicating the spherical, face-centered cubic structure of particles

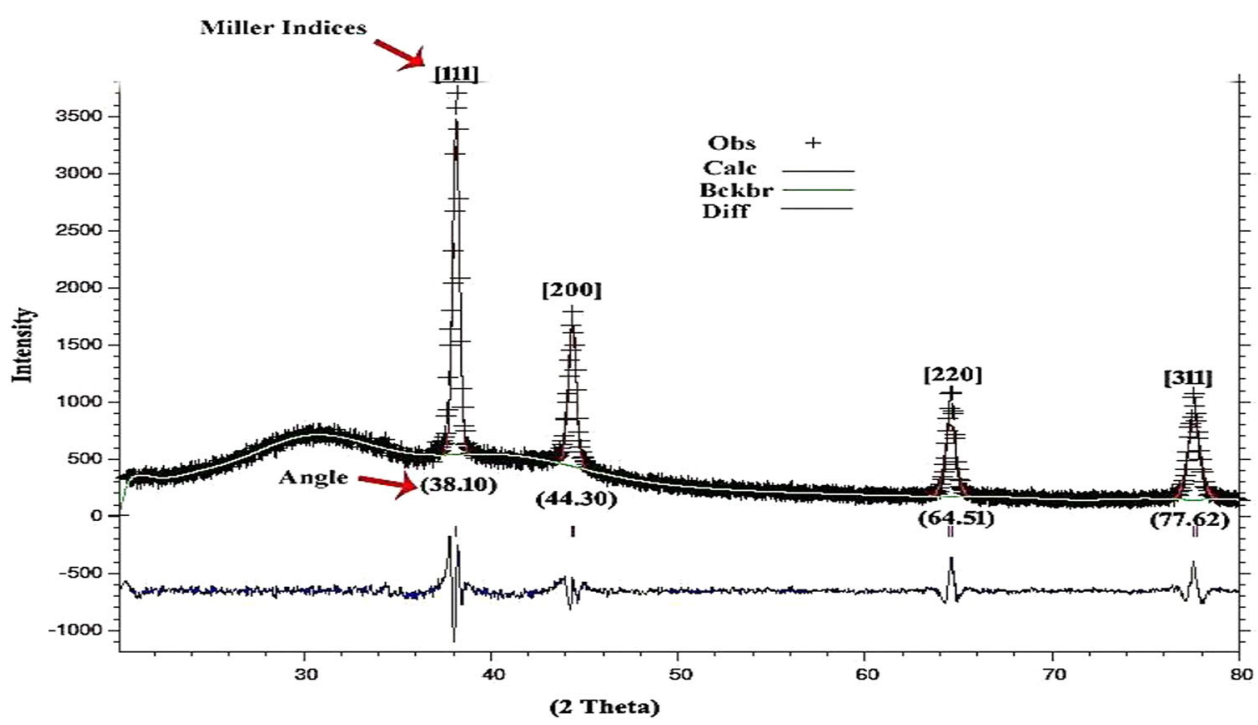

The MDA content of gills and liver tissue showed increase with the increase in the concentration of Ag-NPs after the 14 days of treatment. A significantly high level $(p<0.05)$ was found at $55 \mathrm{mg} \mathrm{L}^{-1}$ concentration which further increases to some extent after 28 days (Table 8 ). The increase in the MDA content of liver and gill tissue indicated the oxidative stress and disturbance of antioxidant system due to broken balance of oxidative and antioxidant system in the Ag-NPs challenged L. rohita. In addition, the MDA content of liver was significantly higher than gill 
Table 1 The structural parameters of Ag-NPs synthesized by the reduction of silver nitrate salts

\begin{tabular}{|c|c|c|c|c|}
\hline Characteristics & Values & & & \\
\hline Miller indices & 111 & 200 & 220 & 311 \\
\hline Diffraction angle & 38.10 & 44.30 & 64.51 & 77.62 \\
\hline Interplanar distance (d) & 2.3634 & 2.04681 & 1.4450 & 1.2311 \\
\hline Lattice constant a $(\AA ̊)$ & 4.0877 & 4.0918 & 4.0869 & 4.0808 \\
\hline Volume of the unit cell $\left(\AA^{3}\right)$ & 68.5972 & 68.2725 & 68.2730 & 68.2729 \\
\hline Crystallite size (nm) & 7.51 & 8.23 & 6.57 & 6.39 \\
\hline$d_{\mathrm{x}}\left(\mathrm{g} / \mathrm{cm}^{3}\right)$ & 6.09 & 6.12 & 6.21 & 6.11 \\
\hline
\end{tabular}

tissue possibly due to damage in liver cells. Additionally, the level of GSH increased and indicates that the liver and gills started defensive mechanism against the oxyraidcals. The level of GSH in liver tissue was found almost twofold compared to gills and this was in response to elevated level of MDA content in liver.

\section{Discussion}

Ag-NPs are extensively used in commercial industry due to large number of nanoproducts (Khan et al. 2015a). The synthesis through cost effective and eco-friendly methods is the challenge of new studies. We synthesized the particles by reducing the $\mathrm{AgNO}_{3}$ with formaldehyde and triethylamine as protecting agent in the reaction. This method is very simple and most commonly used in the synthesis of Ag-NPs (Chaudhari et al. 2007; Pal et al. 2007). This method also ensures the synthesis of particles of various morphologies and desire sizes (Chen and Gao 2007; Kumar
Fig. 5 FT-IR spectra of associated and attached molecules with newly synthesized Ag-NPs particles

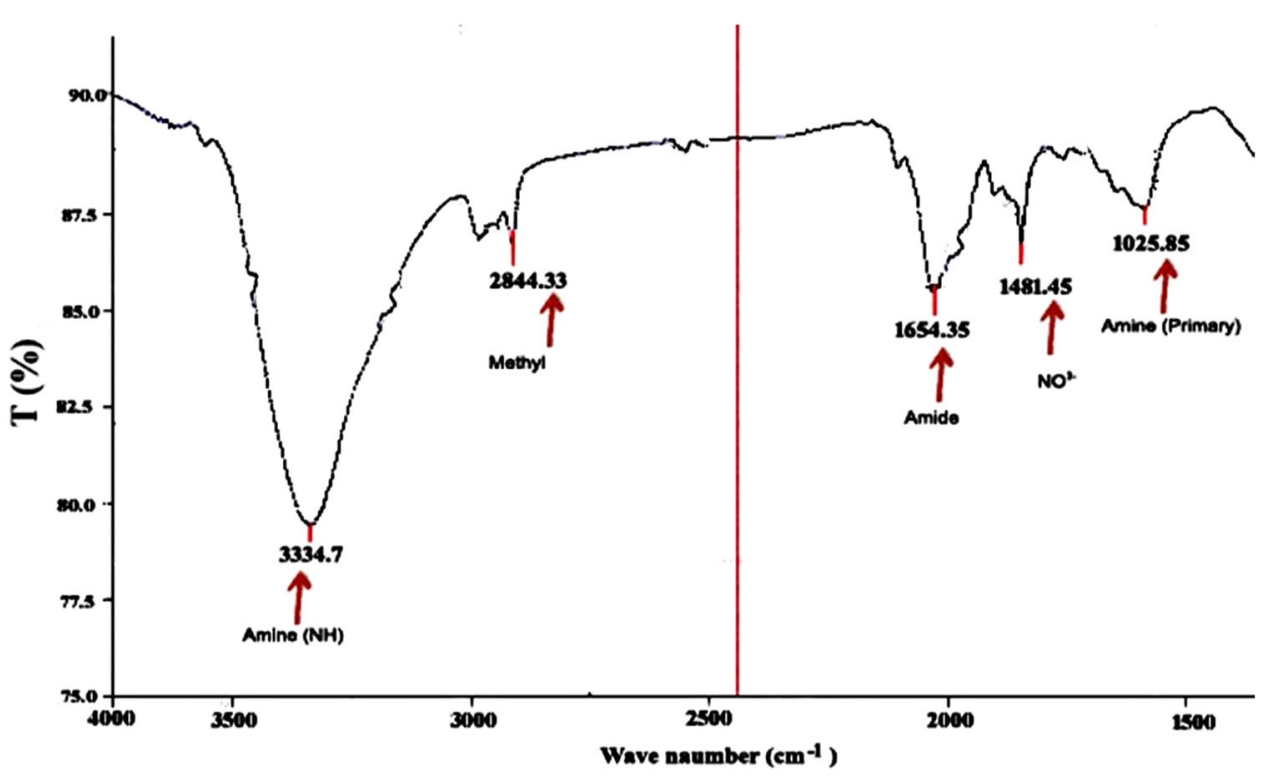

Fig. 6 TEM and bright field image of Ag-NPs
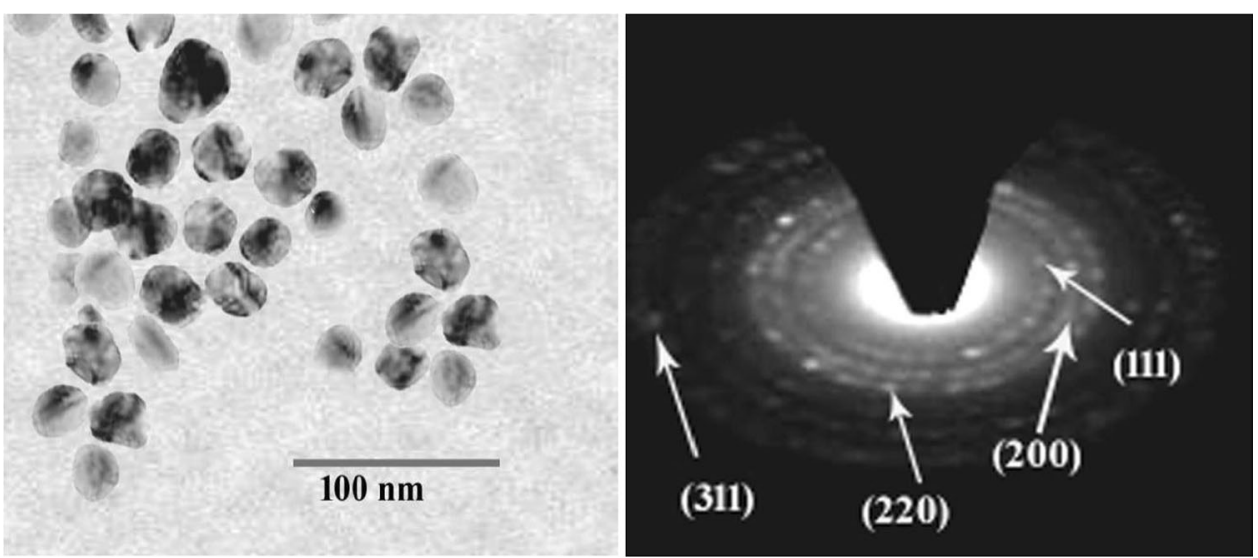

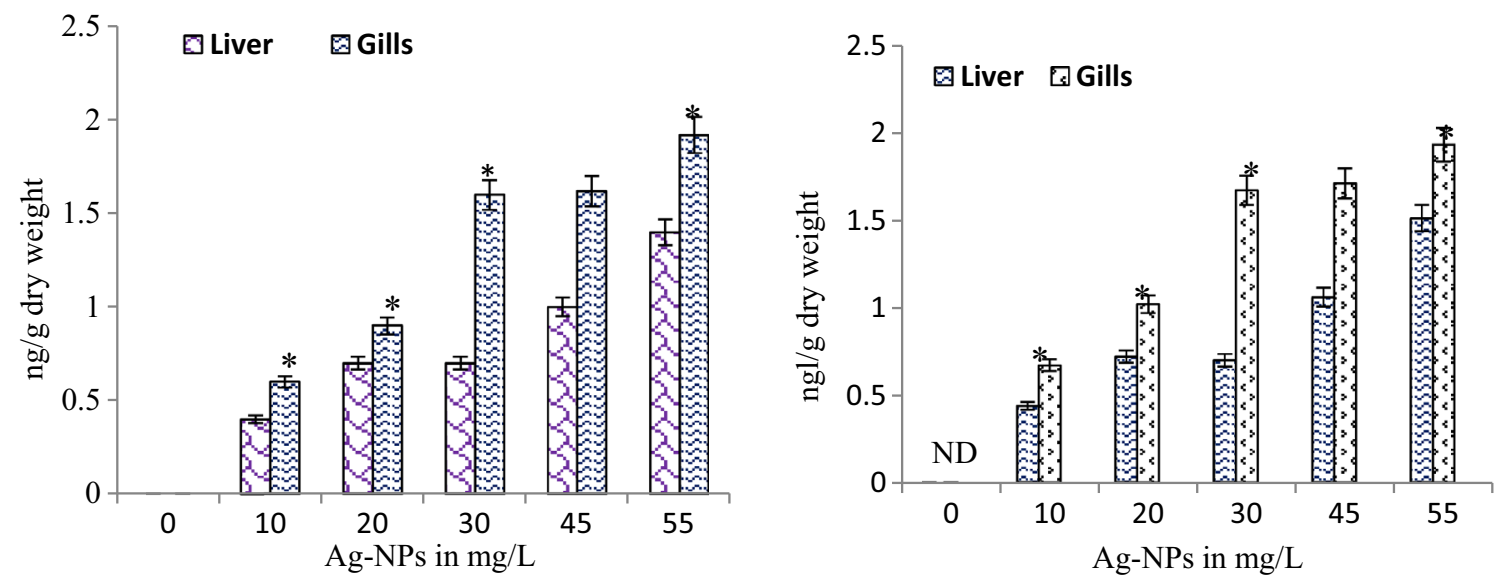

Fig. 7 Silver concentration (Mean $\pm \mathrm{SD}, N=3$ ) in organ of target fish after 14 days (right) 28 days (left). Significantly different $(p<0.05)$ between the organs and marked as asterisk. In the control group the level of the silver was found below the detection limit
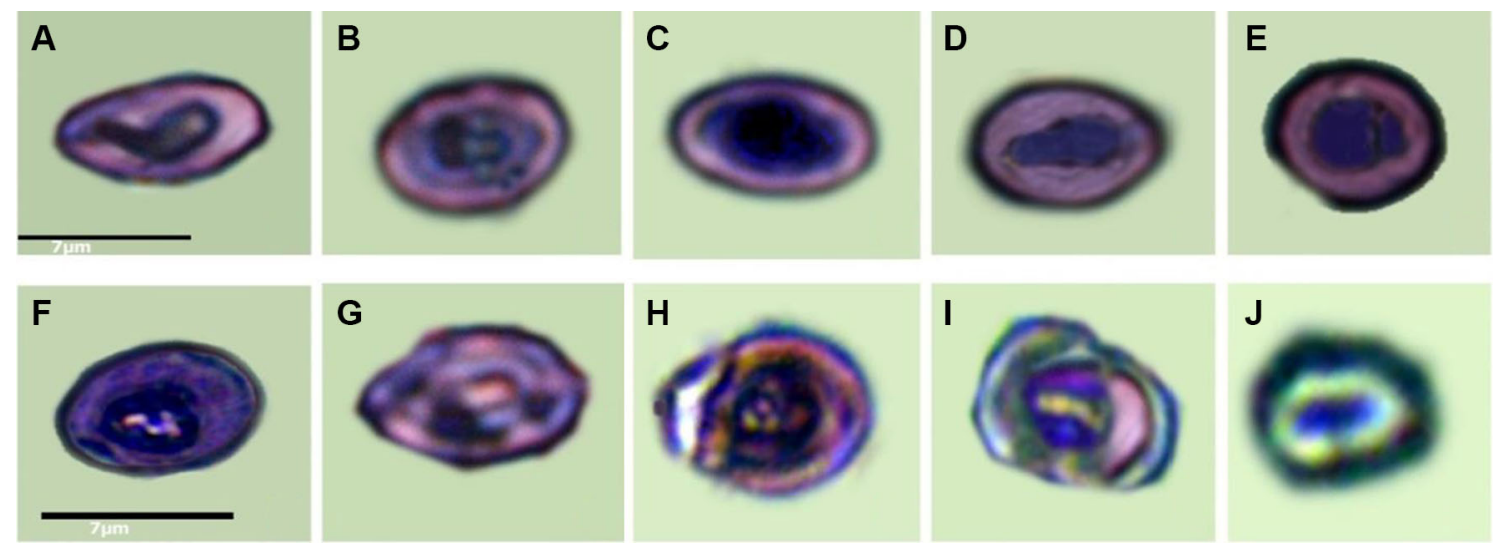

Fig. 8 Photographs of micronuclei (MN) and nuclear abnormalities (NA) performed for erythrocytes of Ag-NPs treated L. rohita. a Notched; b bud; $\mathbf{c}$ others; $\mathbf{d}$ lobed $\mathrm{D}$; $\mathbf{e}$ and $\mathbf{h}$ fragmented; $\mathbf{g} \mathrm{MN} ; \mathbf{i}$ bud; $\mathbf{j}$ others

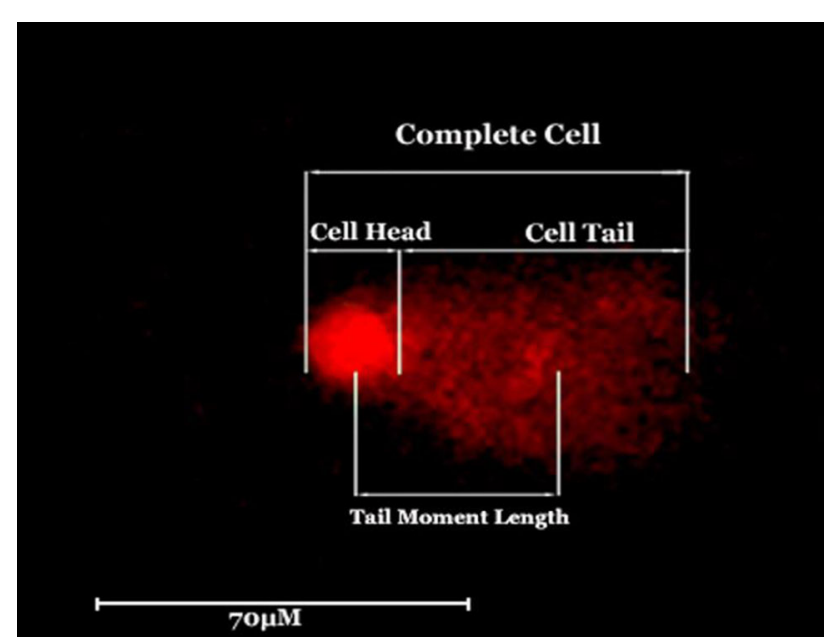

Fig. 9 Tail migration in erythrocytes of L. rohita exposed to Ag-NPs

et al. 2003). Further this method is also very economical with less number of byproducts. Initially, $0.5 \mathrm{Mm}$ of $\mathrm{AgNO}_{3}$ solution was used as precursor and stirred it well.
Few drops of triethylamine act as reaction promoting agent because the reduction through alone formaldehyde is very slow process. When promoting agent was added in the solution, the color of the solution started to change. It suddenly changed to black from colorless as the reducing agent is added. The change in the color was indication of reduction (Rajkumar et al. 2015; Vignesh et al. 2013). The spectroscopic studies also showed a sharp peak nearly $420 \mathrm{~nm}$ at all-time intervals due to plasmon excitation (Kanipandian and Thirumurugan 2014). A basic pH was maintained in reaction using triethylamine at the start for proper reduction of $\mathrm{AgNO}_{3}$ to $\mathrm{Ag}$. The individual particles were agglomerates due to Van der Waals and Coulomb's forces. Triethylamine was used as protecting and stabilizing agent. However, agglomerations seen were due to less or over amount of protecting agent (Fig. 2). The particles were $17.78 \pm 12.12 \mathrm{~nm}$ in average size when particles were analyzed for size analysis. Further the particles were face-centered cubic, spherical and highly crystalline in nature represented by peaks at $38.10 \theta(111), 44.30 \theta$ (200), 
Fig. 10 Comet assay showing four comet classes in the blood erythrocytes of $L$. rohita exposure with different concentration of Ag-NPs. a Without damage; $\mathbf{b}$ class 1 (slightly damage); c class 2 (more or medium damage); d class (highly damage)
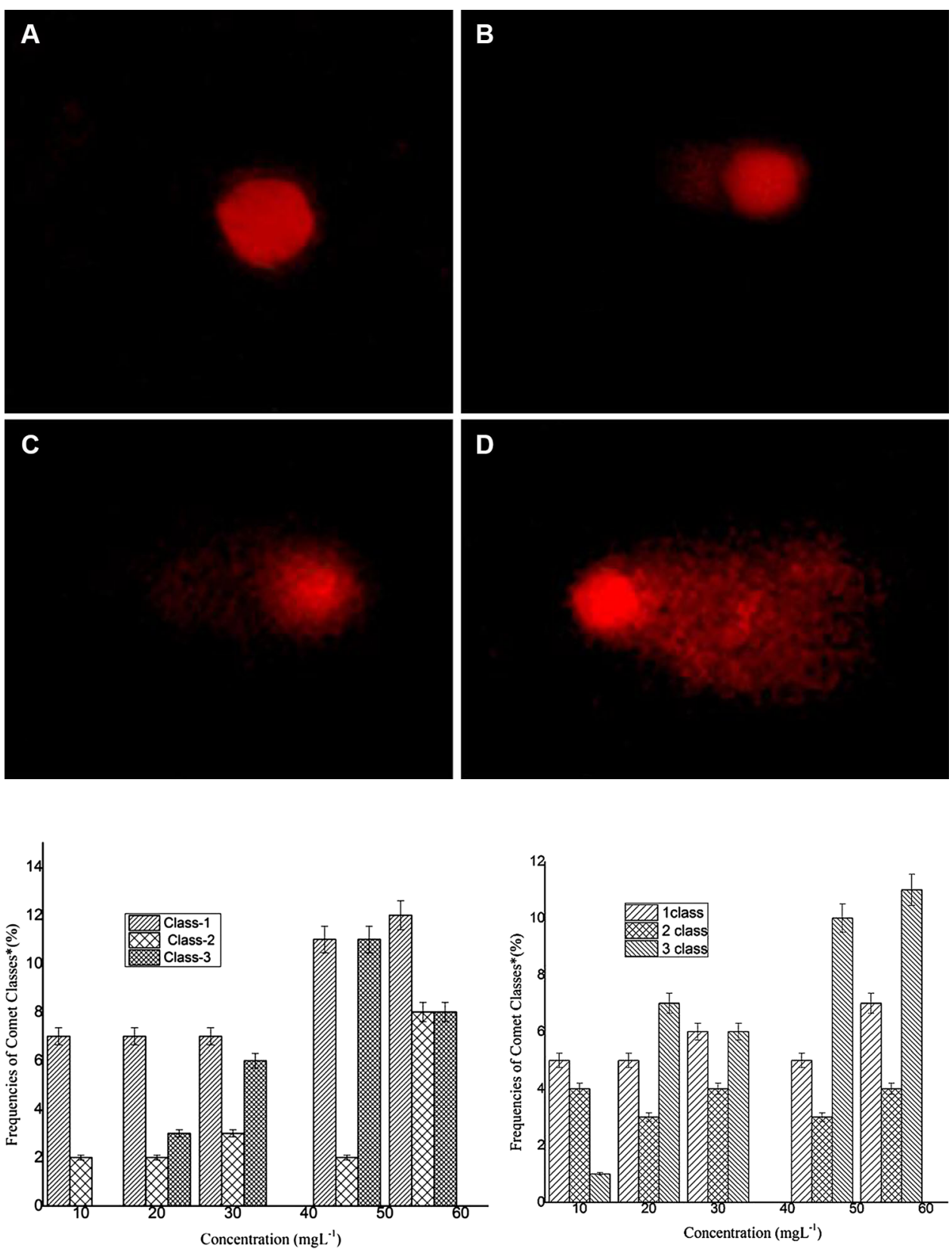

Fig. 11 Frequencies of comet classes after 14 (right) 28 days (left) of Ag-NPs treatment

$64.51 \theta$ (220) and $77.62 \theta$ (311) in the XRD analysis (Kanipandian and Thirumurugan 2014). The sample was highly pure as expected and consists of only Ag and oxygen peaks without any impurity peaks in the EDX analysis (Fig. 3; Table 2). The particles were large might be due to capping agent. The FT-IR spectroscopy conformed the capping and attach compounds to newly synthesized AgNPs. The prominent bands of absorption at $3334.7 \mathrm{~cm}^{-1}$ were characteristics for heterocyclic and amine (NH) stretches. The bands at $2844.33 \mathrm{~cm}^{-1}$ represents methyl or methylene, $1654.35 \mathrm{~cm}^{-1}$ vibrations of amide, $1481.45 \mathrm{~cm}^{-1} \mathrm{NO}_{3}{ }^{-}$and $1025.85 \mathrm{~cm}^{-1}$ primary amide vibrations (Paulraj et al. 2011).
The Ag-NPs cause significant genotoxicity and cytotoxicity due to oxidative stress and inflammation (Asharani et al. 2009; Ivask et al. 2015; Maurer and Meyer 2016). Evidence of published literature suggested that Ag-NPs induce damage to DNA due to double strands breaks, fragmentation and fusions (AshaRani et al. 2008; Kovvuru et al. 2015). This damage was detected through the micronuclei assay. In fish, the micronuclei test of blood erythrocytes is usually preferred because the fish erythrocytes are nucleated in nature. However, the gills and kidney tissues can also be used (Arslan et al. 2015; Bolognesi and Hayashi 2011; Palhares and Grisolia 2002). In the present study, maximum frequency of $\mathrm{MN}(5.03 \pm 1.89 \%)$ was at 
Table 2 Elemental analysis of sample through EDX for sample purity

\begin{tabular}{llllll}
\hline Element & Approximate & Intensity & Weight \% & Weight \% & Atomic \% \\
\hline \multicolumn{3}{c}{ Concentration } & & \multicolumn{3}{c}{ Sigma } \\
O K & 0.05 & 0.3963 & 0.08 & 0.02 & 21.12 \\
Ag L & 1.87 & 0.9982 & 1.88 & 0.03 & 78.95 \\
Totals & & & 1.96 & & \\
\hline
\end{tabular}

Standard: $\mathrm{O}=\mathrm{SiO}_{2}, \mathrm{Ag}=\mathrm{Ag}$

$55 \mathrm{mg} \mathrm{L}^{-1}$ Ag-NPs concentration after 14 and continues to increase. Similar study was performed by Furnus et al. (2014), how recorded slightly different frequency of MN might be due to the difference in the fish species and most probably the environment. They performed the micronuclei assay for nine collected fish species in the River Paraná and revealed the highest MN and NA frequencies in erythrocytes of Steindachnerina brevipinna (Characiformes) significantly different from other species. The bud nuclei were the highest in frequency $3.36 \pm 0.27 \%$ (14 days) and $2.70 \pm 0.61 \%$ (28 days) after the unidentified nuclear alterations designated as others. However, at 14 days and 28 days of treatment the lobed nuclei exceed in frequency than bud nuclei (Tables 3, 4). Unlike micronuclei, the frequencies of NA were found increasing at the highest dose, i.e., $55 \mathrm{mg} \mathrm{L}^{-1}$ of $\mathrm{Ag}$-NPs with the increase of time interval from 14 to 28 days (Table 5). These findings show that the $55 \mathrm{mg} \mathrm{L}^{-1}$ concentration of $\mathrm{Ag}-\mathrm{NPs}$ is highly toxic and produce the genotoxicity beyond the body repair mechanism. Several studies revealed the heavy metals in any forms (micro or nano forms) caused high frequencies of micronuclei and nuclear alterations in fields or laboratory conditions (Isani et al. 2009; Jaffal et al. 2015).

The comet assay is very sensitive and adequate genotoxic method to assess single cell DNA damage. Singn et al. (1988) methodology was adopted with slight modification. This assay is based on the separation of loop of DNA where strands break form supercoiled DNA and allows the quantification of breaks in DNA and alkali labile sites. This loop is free to migrate towards anode in alkaline electrophoresis (Cavas et al. 2005; González-Acevedo et al. 2015). In this study, DNA damage was assessed in the erythrocytes of L. rohita. Ag-NPs increased the frequency of comet cell and \% DNA tail migration in dose dependent manner. Significantly higher comet frequencies $(27.34 \pm 5.68 \%)$ were seen at $55 \mathrm{mg} \mathrm{L}^{-1}$ concentrations

Table 3 Frequency of micronuclei and nuclear abnormalities after 14 days of Ag-NPs exposure in erythrocytes of L. rohita

\begin{tabular}{|c|c|c|c|c|c|c|}
\hline \multirow{2}{*}{$\begin{array}{l}\text { Concentration } \\
\left(\mathrm{mg} \mathrm{L}^{-1}\right)\end{array}$} & \multirow{2}{*}{$\begin{array}{l}\text { Frequency } \\
\text { of MN }\end{array}$} & \multicolumn{5}{|c|}{ Frequency of different classes of NA } \\
\hline & & Fragmented & Lobed & Notched & Bud & Others \\
\hline 0 & $0.1 \pm 0.02^{\mathrm{D}}$ & $0.08 \pm 0.01^{\mathrm{C}}$ & $0.19 \pm 0.04^{\mathrm{C}}$ & $0.04 \pm 0.03^{\mathrm{C}}$ & $0.06 \pm 0.09^{\mathrm{BC}}$ & $0.15 \pm 0.05^{\mathrm{C}}$ \\
\hline 10 & $1.91 \pm 0.92^{\mathrm{C}}$ & $0.89 \pm 0.24^{\mathrm{BC}}$ & $3.55 \pm 0.57^{\mathrm{AB}}$ & $0.17 \pm 0.11^{\mathrm{C}}$ & $1.570 \pm 1.02^{\mathrm{B}}$ & $1.27 \pm 0.64^{\mathrm{BC}}$ \\
\hline 20 & $3.18 \pm 1.19^{\mathrm{BC}}$ & $1.97 \pm 0.23^{\mathrm{A}}$ & $4.76 \pm 0.31^{\mathrm{A}}$ & $0.62 \pm 0.22^{\mathrm{BC}}$ & $0.30 \pm 0.16^{\mathrm{C}}$ & $1.43 \pm 0.73^{\mathrm{BC}}$ \\
\hline 30 & $4.35 \pm 1.69^{\mathrm{AB}}$ & $1.96 \pm 0.46^{\mathrm{A}}$ & $2.90 \pm 0.75^{\mathrm{B}}$ & $2.71 \pm 1.44^{\mathrm{A}}$ & $1.02 \pm 0.17^{\mathrm{BC}}$ & $2.32 \pm 1.41^{\mathrm{B}}$ \\
\hline 45 & $4.59 \pm 1.67^{\mathrm{AB}}$ & $1.96 \pm 0.58^{\mathrm{A}}$ & $2.85 \pm 1.14^{\mathrm{B}}$ & $0.267 \pm 0.11^{\mathrm{C}}$ & $1.01 \pm 0.16^{\mathrm{BC}}$ & $2.27 \pm 0.91^{\mathrm{B}}$ \\
\hline 55 & $5.03 \pm 1.89^{\mathrm{A}}$ & $1.77 \pm 0.20^{\mathrm{AB}}$ & $4.05 \pm 0.33^{\mathrm{AB}}$ & $2.14 \pm 0.49^{\mathrm{AB}}$ & $3.36 \pm 0.27^{\mathrm{A}}$ & $4.81 \pm 1.95^{\mathrm{A}}$ \\
\hline
\end{tabular}

Frequencies were calculated per 1000 cells and three slides per treatment represented as mean \pm SD

The other abnormalities are the nuclear abnormalities that are not fitted into the mentioned nuclear abnormalities

Values in the same column not sharing the same letter are significantly different $5 \%$ level

Table 4 Frequency of micronuclei and nuclear abnormalities after 28 days of Ag-NPs exposure in erythrocytes of $L$. rohita

\begin{tabular}{|c|c|c|c|c|c|c|}
\hline \multirow{2}{*}{$\begin{array}{l}\text { Concentration } \\
\left(\mathrm{mg} \mathrm{L}^{-1}\right)\end{array}$} & \multirow{2}{*}{$\begin{array}{l}\text { Frequency } \\
\text { of MN a }\end{array}$} & \multicolumn{5}{|c|}{ Frequency of different classes of NA } \\
\hline & & Fragmented & Lobed & Notched & Bud & Others $^{\mathrm{b}}$ \\
\hline 0 & $0.01 \pm 0.01^{\mathrm{C}}$ & $0.04 \pm 0.15^{\mathrm{C}}$ & $0.17 \pm 0.02^{\mathrm{C}}$ & $0.02 \pm 0.01^{\mathrm{C}}$ & $0.03 \pm 0.02^{\mathrm{C}}$ & $0.13 \pm 0.05^{\mathrm{C}}$ \\
\hline 10 & $1.69 \pm 0.43^{\mathrm{C}}$ & $0.89 \pm 0.24^{\mathrm{BC}}$ & $3.64 \pm 0.50^{\mathrm{AB}}$ & $0.17 \pm 0.11^{\mathrm{C}}$ & $1.57 \pm 1.02^{\mathrm{B}}$ & $1.27 \pm 0.64^{\mathrm{BC}}$ \\
\hline 20 & $3.79 \pm 1.75^{\mathrm{B}}$ & $1.973 \pm 0.62^{\mathrm{AB}}$ & $4.62 \pm 0.53^{\mathrm{A}}$ & $0.45 \pm 0.37^{\mathrm{BC}}$ & $0.30 \pm 0.16^{\mathrm{C}}$ & $1.43 \pm 0.73^{\mathrm{BC}}$ \\
\hline 30 & $5.16 \pm 2.60^{\mathrm{AB}}$ & $1.96 \pm 0.45^{\mathrm{A}}$ & $2.61 \pm 0.18^{\mathrm{B}}$ & $2.71 \pm 1.44^{\mathrm{A}}$ & $0.92 \pm 0.34^{\mathrm{BC}}$ & $2.31 \pm 0.41^{\mathrm{B}}$ \\
\hline 45 & $5.17 \pm 2.79^{\mathrm{AB}}$ & $1.96 \pm 0.58^{\mathrm{A}}$ & $0.88 \pm 0.41^{\mathrm{C}}$ & $0.27 \pm 0.11^{\mathrm{B}}$ & $0.60 \pm 0.52^{\mathrm{BC}}$ & $2.27 \pm 0.91^{\mathrm{BC}}$ \\
\hline 55 & $6.31 \pm 2.63^{\mathrm{A}}$ & $1.77 \pm 0.20^{\mathrm{A}}$ & $3.42 \pm 1.01^{\mathrm{AB}}$ & $1.47 \pm 0.76^{\mathrm{A}}$ & $2.70 \pm 0.61^{\mathrm{A}}$ & $4.81 \pm 1.94^{\mathrm{A}}$ \\
\hline
\end{tabular}

Frequencies were calculated per 1000 cells and three slides per treatment represented as mean \pm SD

The other alterations are the nuclear abnormalities that are not fitted into the mentioned nuclear abnormalities

Values in the same column not sharing the same letter are significantly different $5 \%$ level 
Table 5 Total nuclear alterations (NA) in the erythrocytes of $L$. rohita exposed to different concentrations of Ag-NPs for period of 28 days

\begin{tabular}{lcc}
\hline Concentration $\left(\mathrm{mg} \mathrm{L}^{-1}\right)$ & 14 days & 28 days \\
\hline 0 & $0.62 \pm 0.2^{\mathrm{C}}$ & $0.4 \pm 0.1^{\mathrm{D}}$ \\
10 & $7.45 \pm 2.19^{\mathrm{B}}$ & $7.61 \pm 1.08^{\mathrm{C}}$ \\
20 & $9.083 \pm 2.52^{\mathrm{B}}$ & $9.30 \pm 0.76^{\mathrm{BC}}$ \\
30 & $10.90 \pm 2.14^{\mathrm{B}}$ & $12.51 \pm 2.44^{\mathrm{AB}}$ \\
45 & $8.35 \pm 2.54^{\mathrm{B}}$ & $7.57 \pm 0.42^{\mathrm{C}}$ \\
55 & $15.47 \pm 1.45^{\mathrm{A}}$ & $16.34 \pm 2.71^{\mathrm{A}}$ \\
\hline
\end{tabular}

Total nuclear alterations are sum of frequencies of fragmented, lobed, notched, bud and other nuclear alterations, i.e., $-\mathrm{X}=\sum \mathrm{f}$ ( $\mathrm{f}=$ frequency of all the alterations)

Values in the same column not sharing the same letter are significantly different $5 \%$ level

after 14 days of treatment then gradual decrease in the frequency (Table 6). Buschini et al. (2004) performed the comet assay on the erythrocytes of Cyprinus carpio to detect the possible genotoxic effects of disinfectants treated surface water. They found that comet and frequency of micronuclei was at the highest when erythrocytes were directly exposed to disinfected sodium hypochlorite and chloride. The similar findings were observed in the present study where the increase in the frequency of comet cells increase with the increase in the concentration of Ag-NPs. The DNA tail migration was $48.67 \pm 7.51 \mu \mathrm{m}$ when the blood was sampled after the 14 days and then decreased to $43.0 \pm 3.46 \mu \mathrm{m}$ after 28 days sampling due to DNA repair mechanisms followed by removal of damaging agent (Karlsson 2010; Karlsson et al. 2015). A similar result was recorded by Rocha et al. (2011) in the erythrocytes of Aequidens treated with different concentration of methyl mercury. The fish erythrocytes showed increase in tailed of nucleoid when treated with $\mathrm{MeHg}(p<0.0001)$.

The incidence of the comet was divided into three classes; slight damage (class 1), moderate damage (class 2) and severe damage (class 3 ) as shown in Figs. 10, 11. At low Ag-NPs concentration $\left(10-30 \mathrm{mg} \mathrm{L}^{-1}\right)$, the erythrocytes were slightly damaged as represented by class 1 ; became severely damage with the increasing concentration. The frequency of severely damaged cells (class 3) was highest among all the classes at $55 \mathrm{mg} \mathrm{L}^{-1}$ concentration due to damaging the DNA repair mechanism. The frequency of severely damaged cells decreases after 28 days Ag-NPs treatment. This can be explained on the basis of the fact that slight and moderate damaged to genetic

Table 6 Frequencies of erythrocytes comet cells and in DNA tail migration in response Ag-NPs treatment in L. rohita after 14 and 28 days

\begin{tabular}{|c|c|c|c|c|}
\hline \multirow{2}{*}{$\begin{array}{l}\text { Concentration } \\
\left(\mathrm{mg} \mathrm{L}^{-1}\right)\end{array}$} & \multicolumn{2}{|c|}{ Comet (per 100 cells analyzed) } & \multicolumn{2}{|c|}{ DNA tail migration length $(\mu \mathrm{m})$} \\
\hline & 14 days & 28 days & 14 days & 28 days \\
\hline Control & $4.67 \pm 2.08^{\mathrm{D}}$ & $4.33 \pm 2.51^{\mathrm{C}}$ & $4.67 \pm 1.53^{\mathrm{D}}$ & $6.01 \pm 2.65^{\mathrm{D}}$ \\
\hline 10 & $8.33 \pm 1.51^{\mathrm{CD}}$ & $10.00 \pm 1.73^{\mathrm{BC}}$ & $22.34 \pm 3.06^{\mathrm{C}}$ & $13.33 \pm 2.08^{\mathrm{CD}}$ \\
\hline 20 & $12.0 \pm 1.73^{\mathrm{CD}}$ & $14.67 \pm 1.53^{\mathrm{AB}}$ & $28.66 \pm 2.52^{\mathrm{BC}}$ & $24.0 \pm 6.01^{\mathrm{BC}}$ \\
\hline 30 & $15.67 \pm 3.05^{\mathrm{BC}}$ & $13.67 \pm 2.08^{\mathrm{B}}$ & $33.34 \pm 4.93^{\mathrm{BC}}$ & $29.32 \pm 8.02^{\mathrm{AB}}$ \\
\hline 45 & $24.0 \pm 3.00^{\mathrm{AB}}$ & $17.33 \pm 2.08^{\mathrm{AB}}$ & $39.34 \pm 7.02^{\mathrm{AB}}$ & $33.0 \pm 5.30^{\mathrm{AB}}$ \\
\hline 55 & $27.34 \pm 5.68^{\mathrm{A}}$ & $22.65 \pm 6.66^{\mathrm{A}}$ & $48.67 \pm 7.51^{\mathrm{A}}$ & $43.0 \pm 3.46^{\mathrm{A}}$ \\
\hline
\end{tabular}

Frequencies were calculated per 100 cells and three slides per treatment represented as mean \pm SD

Values in the same column not sharing the same letter are significantly different $5 \%$ level

Table 7 Change in the activities of selective enzymes in the liver and gill tissues after 14 days treatment

\begin{tabular}{|c|c|c|c|c|c|c|}
\hline \multirow{2}{*}{$\begin{array}{l}\text { Concentration } \\
\left(\mathrm{mg} \mathrm{L}^{-1}\right)\end{array}$} & \multicolumn{3}{|l|}{ Liver tissue } & \multicolumn{3}{|l|}{ Gill tissue } \\
\hline & $\begin{array}{l}\text { GST (mol/mg } \\
\text { protein) }\end{array}$ & $\begin{array}{l}\mathrm{GSH}\left(\mu \mathrm{mol} \mathrm{g}{ }^{-1}\right. \\
\text { protein) }\end{array}$ & $\begin{array}{l}\text { MDA }\left(\mu \mathrm{mol} \mathrm{g}{ }^{-1}\right. \\
\text { protein) }\end{array}$ & $\begin{array}{l}\text { GST (mol mg } \\
\text { protein) }\end{array}$ & $\begin{array}{l}\mathrm{GSH}\left(\mu \mathrm{mol} \mathrm{g}{ }^{-1}\right. \\
\text { protein) }\end{array}$ & $\begin{array}{l}\text { MDA }\left(\mu \mathrm{mol} \mathrm{g}{ }^{-1}\right. \\
\text { protein) }\end{array}$ \\
\hline Control & $0.067 \pm 0.1^{\mathrm{A}}$ & $1.17 \pm 0.05^{\mathrm{D}}$ & $5.55 \pm 1.23^{\mathrm{E}}$ & $0.061 \pm 0.02^{\mathrm{A}}$ & $0.94 \pm 0.03^{\mathrm{D}}$ & $4.21 \pm 1.04^{\mathrm{E}}$ \\
\hline 10 & $0.019 \pm 0.004^{\mathrm{C}}$ & $2.12 \pm 0.96^{\mathrm{C}}$ & $10.02 \pm 2.17^{\mathrm{D}}$ & $0.015 \pm 0.01^{\mathrm{C}}$ & $1.54 \pm 0.04^{\mathrm{C}}$ & $6.73 \pm 2.00^{\mathrm{E}}$ \\
\hline 20 & $0.016 \pm 0.009^{C}$ & $2.52 \pm 0.44^{\mathrm{BC}}$ & $28.77 \pm 5.63^{C}$ & $0.009 \pm 0.006^{\mathrm{C}}$ & $1.76 \pm 0.34^{\mathrm{B}}$ & $20.33 \pm 4.89^{\mathrm{D}}$ \\
\hline 30 & $0.02 \pm 0.001^{\mathrm{E}}$ & $2.57 \pm 0.23^{\mathrm{B}}$ & $30.91 \pm 4.27^{\mathrm{C}}$ & $0.027 \pm 0.003^{\mathrm{B}}$ & $1.83 \pm 0.23^{\mathrm{B}}$ & $21.57 \pm 4.23^{\mathrm{C}}$ \\
\hline 45 & $0.027 \pm 0.012^{\mathrm{B}}$ & $3.44 \pm 0.52^{\mathrm{A}}$ & $74.45 \pm 9.44^{\mathrm{B}}$ & $0.021 \pm 0.007^{\mathrm{B}}$ & $2.37 \pm 0.75^{\mathrm{AB}}$ & $50.67 \pm 8.57^{\mathrm{B}}$ \\
\hline 55 & $0.006 \pm 0.00^{\mathrm{D}}$ & $3.99 \pm 0.51^{\mathrm{A}}$ & $97.11 \pm 15.23^{\mathrm{A}}$ & $0.01 \pm 0.005^{\mathrm{E}}$ & $2.86 \pm 0.64^{\mathrm{A}}$ & $66.83 \pm 8.21^{\mathrm{A}}$ \\
\hline
\end{tabular}

Values are mean \pm SD of three replicates

Values in the same column not sharing the same letter are significantly different $5 \%$ level 
Table 8 Change in the activities of selective enzymes in the liver and gill tissues after 28 days treatment

\begin{tabular}{|c|c|c|c|c|c|c|}
\hline \multirow{2}{*}{$\begin{array}{l}\text { Concentration } \\
\left(\mathrm{mg} \mathrm{L}^{-1}\right)\end{array}$} & \multicolumn{3}{|l|}{ Liver tissue } & \multicolumn{3}{|l|}{ Gill tissue } \\
\hline & $\begin{array}{l}\mathrm{GST}\left(\mathrm{mol} \mathrm{mg}{ }^{-1}\right. \\
\text { protein) }\end{array}$ & $\begin{array}{l}\mathrm{GSH}\left(\mu \mathrm{mol} \mathrm{g}{ }^{-1}\right. \\
\text { protein })\end{array}$ & $\begin{array}{l}\text { MDA }\left(\mu \mathrm{mol} \mathrm{g}^{-1}\right. \\
\text { protein) }\end{array}$ & $\begin{array}{l}\mathrm{GST}\left(\mathrm{mol} \mathrm{mg}{ }^{-1}\right. \\
\text { protein) }\end{array}$ & $\begin{array}{l}\mathrm{GSH}\left(\mu \mathrm{mol} \mathrm{g}{ }^{-1}\right. \\
\text { protein })\end{array}$ & $\begin{array}{l}\text { MDA }\left(\mu \mathrm{mol} \mathrm{g}^{-1}\right. \\
\text { protein) }\end{array}$ \\
\hline Control & $0.057 \pm 0.012^{\mathrm{A}}$ & $1.19 \pm 0.15^{\mathrm{D}}$ & $6.21 \pm 2.15^{\mathrm{E}}$ & $0.061 \pm 0.021^{\mathrm{A}}$ & $0.92 \pm 0.29^{\mathrm{D}}$ & $4.45 \pm 2.77^{\mathrm{D}}$ \\
\hline 10 & $0.019 \pm 0.011^{\mathrm{B}}$ & $2.18 \pm 0.54^{\mathrm{C}}$ & $13.23 \pm 2.98^{\mathrm{D}}$ & $0.015 \pm 0.07^{\mathrm{C}}$ & $1.52 \pm 0.24^{\mathrm{C}}$ & $6.89 \pm 2.44^{\mathrm{D}}$ \\
\hline 20 & $0.016 \pm 0.009^{\mathrm{BC}}$ & $2.57 \pm 0.24^{\mathrm{C}}$ & $28.81 \pm 6.93^{\mathrm{C}}$ & $0.009 \pm 0.002^{\mathrm{C}}$ & $1.72 \pm 0.53^{\mathrm{BC}}$ & $21.15 \pm 7.45^{\mathrm{C}}$ \\
\hline 30 & $0.02 \pm 0.01^{\mathrm{D}}$ & $2.60 \pm 0.65^{\mathrm{C}}$ & $31.33 \pm 6.23^{\mathrm{C}}$ & $0.08 \pm 0.02^{\mathrm{C}}$ & $1.85 \pm 0.44^{\mathrm{B}}$ & $21.57 \pm 8.22^{\mathrm{C}}$ \\
\hline 45 & $0.024 \pm 0.012^{\mathrm{C}}$ & $3.56 \pm 0.94^{\mathrm{B}}$ & $78.35 \pm 12.78^{\mathrm{B}}$ & $0.035 \pm 0.02^{\mathrm{B}}$ & $2.47 \pm 0.89^{\mathrm{A}}$ & $50.98 \pm 6.49^{\mathrm{B}}$ \\
\hline 55 & $0.006 \pm 0.004^{\mathrm{D}}$ & $4.03 \pm 0.24^{\mathrm{A}}$ & $99.78 \pm 15.76^{\mathrm{A}}$ & $0.01 \pm 0.00^{\mathrm{D}}$ & $2.93 \pm 0.88^{\mathrm{A}}$ & $67.11 \pm 8.67^{\mathrm{A}}$ \\
\hline
\end{tabular}

materials possibly eliminated by repair mechanism. The high concentration and prolonged exposure time damaged the repair mechanism in the severely damaged cells, hence failed to repair, and their frequency remain higher at higher concentration after 28 days of treatment. Janaina et al. (2005) recorded the similar comet classes in Corbicula fluminea (Mollusca) tissues exposed to methyl methane sulfonate for $40 \mathrm{~min}$ to concentration of $0.6,1.2$ or $2.4 \times 10^{-4} \mathrm{M}$. They used hemolymph, gill and digestive gland tissues to evaluate the DNA damage and found the highest damage in the gill tissues with all the comet classes from no damage to severe damage. Further, Hoshina and Marin-Morales (2010) also uses the comet classes to demonstrate the damage to DNA in the erythrocytes of Oreochromis niloticus sampled in the water with petroleum refinery effluents of Atibaia and Jaguarí rivers. They observed a high level of damage in the cells of fishes exposed to refinery effluents. They further recorded the petroleum refinery effluents producing genotoxicity even after the treatment.

In general, the pattern of the distribution was found similar in all test material. However, the accumulation was higher in the gill samples compared to liver possibly due to direct contact with the contaminated water. The highest concentration in the decreasing order was gills and liver. In spite of high dose $\left(55 \mathrm{mg} \mathrm{L}^{-1}\right)$ very limited amount was accumulated in the liver gills and plasma due to distribution in other organs including intestine, stomach, kidney, muscle and brain tissues. Second, large amount of particles might be lost through fecal material and some settle down in the aquaria. Several studies have also suggested the distribution of silver in tissue including skin, bone marrow, liver, spleen, kidney, heart, thyroid gland, adrenal gland, pancreases, brain and lymph node (Pfurtscheller et al. 2014). Further these results are also comparable to Boudreau et al. (2016) in the case of 13 weeks administrated Sprague-Dawley rats. They found a dose dependent and significant accumulation detected in the tissues by ICP-MS in the liver, kidney, jejunum and colon. The accumulated particles cause oxidative stress which is one of the most important factor in toxicity of nanoparticles $(\mathrm{Nel}$ et al. 2006). A possible role of the stress is damage to DNA and induction of apoptosis (Simonian and Coyle 1996). In this study, there was a sharp decline in the activities of GST in both gill and liver tissue and significantly different at each treatment after 14 days. The value of GST also fluctuated at 30 $\mathrm{mg} \mathrm{L}^{-1}$ where the level was found higher in the gill tissue compared to liver (Table 7).

The level of hepatic and gill MDA was sharply raised in all treated group as compared to the control. This increased level indicates that Ag-NPs induced the production of oxyradicals in the gills and liver tissue. Similarly, the increase level of GSH suggested that liver and gill tissues respond in defence against the increase level of oxyradicals. Some other studies also represented the conditions where the level of GSH increased due to xenobiotic and nanoparticles (Arora et al. 2009). Further GSH is also cofactor for GST and enhance the activity of this enzyme against free radicals in the oxidative stress (Table 8).

\section{Conclusion}

It was concluded that Ag-NPs induced significant damage to the genetic material in the test fish which causes nuclear alterations in blood erythrocytes. The damage increases when the dose or time interval of the exposure increases. Further, Ag-NPs also produce oxidative stress. These findings are mainly focused on the toxicological effects of Ag-NPs. The signaling cascades in response of Ag-NPs that induce damage and the molecular repair mechanisms are still to be exposed in the future studies.

Acknowledgements The author is very thankful to Department of Zoology Government College University and National textile University Faisalabad for providing the lab facilities in conducting this work. The authors are also graceful to the staff of research lab, Department of Zoology for providing the support in completing this research. This article is part of the corresponding author's Ph. D work

Compliance with ethical standards 
Conflict of interest The authors declared that they have no conflict of interest

Open Access This article is distributed under the terms of the Creative Commons Attribution 4.0 International License (http:// creativecommons.org/licenses/by/4.0/), which permits unrestricted use, distribution, and reproduction in any medium, provided you give appropriate credit to the original author(s) and the source, provide a link to the Creative Commons license, and indicate if changes were made.

\section{References}

Ahamed M, Karns M, Goodson M, Rowe J, Hussain SM, Schlager JJ, Hong Y (2008) DNA damage response to different surface chemistry of silver nanoparticles in mammalian cells. Toxicol Appl Pharmacol 233:404-410. doi:10.1016/j.taap.2008.09.015

Arora S, Jain J, Rajwade J, Paknikar K (2009) Interactions of silver nanoparticles with primary mouse fibroblasts and liver cells. Toxicol Appl Pharmacol 236:310-318. doi:10.1016/j.taap.2009. 02.020

Arslan ÖÇ, Boyacioğlu M, Parlak H, Katalay S, Karaaslan MA (2015) Assessment of micronuclei induction in peripheral blood and gill cells of some fish species from Aliağa Bay Turkey. Mar Pollut Bull 94:48-54. doi:10.1016/j.marpolbul.2015.03.018

AshaRani P, Low Kah Mun G, Hande MP, Valiyaveettil S (2008) Cytotoxicity and genotoxicity of silver nanoparticles in human cells. ACS Nano 3:279-290

Asharani P, Hande MP, Valiyaveettil S (2009) Anti-proliferative activity of silver nanoparticles. BMC Cell Biol 10:65. doi:10. 1186/1471-2121-10-65

Awasthi KK, Awasthi A, Bhoot N, John P, Sharma SK, Awasthi K (2013) Antimicrobial properties of electro-chemically stabilized organo-metallic thin films. Adv Electrochem 1:42-47. doi:10. 1166/adel.2013.1013

Benn TM, Westerhoff P (2008) Nanoparticle silver released into water from commercially available sock fabrics. Environ Sci Technol 42:4133-4139. doi:10.1021/es7032718

Bolognesi C, Hayashi M (2011) Micronucleus assay in aquatic animals Mutagen 26:205-213. doi:10.1093/mutage/geq073

Boudreau MD, Imam MS, Paredes AM, Bryant MS, Cunningham CK, Felton RP, Jones MY, Davis KJ, Olson GR (2016) Differential Effects of Silver Nanoparticles and Silver Ions on Tissue Accumulation, Distribution, and Toxicity in the Sprague Dawley Rat Following Daily Oral Gavage Administration for 13-Weeks Toxicol Sci kfv318 doi:10.1093/toxsci/kfv318

Buschini A, Martino A, Gustavino B, Monfrinotti M, Poli P, Rossi C, Santoro M, Dörr A, Rizzoni M (2004) Comet assay and micronucleus test in circulating erythrocytes of Cyprinus carpio specimens exposed in situ to lake waters treated with disinfectants for potabilization Mutat Res Gen Tox En 557:119-129. doi:10.1016/j.mrgentox.2003.10.008

Carrasco KR, Tilbury KL, Myers MS (1990) Assessment of the piscine micronucleus test as an in situ biological indicator of chemical contaminant effects. Can J Fish Aquat Sci 47:2123-2136. doi:10.1139/f90-237

Cavas T, Garanko NN, Arkhipchuk VV (2005) Induction of micronuclei and binuclei in blood, gill and liver cells of fishes subchronically exposed to cadmium chloride and copper sulphate. Food Chem Toxicol 43:569-574. doi:10.1016/j.fct. 2004.12.014

Chaudhari VR, Haram SK, Kulshreshtha S, Bellare J, Hassan P (2007) Micelle assisted morphological evolution of silver nanoparticles. Colloids Surf A Physicochem Eng Asp 301:475-480

Chen Z, Gao L (2007) A facile and novel way for the synthesis of nearly monodisperse silver nanoparticles. Mater Res Bull 42:1657-1661

Devi GP, Ahmed KBA, Varsha MS, Shrijha B, Lal KS, Anbazhagan V, Thiagarajan R (2015) Sulfidation of silver nanoparticle reduces its toxicity in zebrafish. Aquat Toxicol 158:149-156. doi:10.1016/j.aquatox.2014.11.007

Furnus G, Caffetti J, García E, Benítez M, Pastori M, Fenocchio A (2014) Baseline micronuclei and nuclear abnormalities frequencies in native fishes from the Paraná River (Argentina) Braz. J Biol 74:217-221. doi:10.1590/1519-6984.13712

Gliga AR, Skoglund S, Wallinder IO, Fadeel B, Karlsson HL (2014) Size-dependent cytotoxicity of silver nanoparticles in human lung cells: the role of cellular uptake, agglomeration and $\mathrm{Ag}$ release. Part Fibre Toxicol 11:1-17. doi:10.1186/1743-8977-11-11

González-Acevedo A, García-Salas JA, Gosálvez J, Fernández JL, Dávila-Rodríguez MI, Cerda-Flores RM, Méndez-López LF, Cortés-Gutiérrez EI (2015) Evaluation of environmental genotoxicity by comet assay in Columba livia Toxicol Mech Methods:1-6 doi:10.3109/15376516.2015.1114059

Habig WH, Pabst MJ, Jakoby WB (1974) Glutathione S-transferases the first enzymatic step in mercapturic acid formation. J Biol Chem 249:7130-7139

Hamid A, Khan MU, Yaqoob J, Umar A, Rehman A, Javed S, Sohail A, Anwar A, Khan MS, Ali A (2016) Assessment of mercury load in river Ravi, urban sewage streams of Lahore Pakistan and its impact on the oxidative stress of exposed fish. J Bio Environ Sci 8:63-72

Hoshina M, Marin-Morales M (2010) Evaluation of the genotoxicity of petroleum refinery effluents using the comet assay in Oreochromis niloticus (Nile tilapia). J Braz Soc Ecotoxicol 5:75-79 doi:10.5132/jbse.2010.01.012

Igwilo IO, Afonne OJ, Maduabuchi UJ-M, Orisakwe OE (2006) Toxicological study of the Anam river in Otuocha, Anambra state, Nigeria. Arch Environ Occup Health 61:205-208. doi:10. 3200/aeoh.61.5.205-208

Iravani HK, Mirmohammadi S, B Zolfaghari S (2014) Synthesis of silver nanoparticles: chemical, physical and biological methods Res Pharm Sci 9:385-406

Isani G, Andreani G, Cocchioni F, Fedeli D, Carpene E, Falcioni G (2009) Cadmium accumulation and biochemical responses in Sparus aurata following sub-lethal $\mathrm{Cd}$ exposure. Ecotoxicol Environ Saf 72:224-230. doi:10.1016/j.ecoenv.2008.04.015

Ivask A, Voelcker NH, Seabrook SA, Hor M, Kirby JK, Fenech M, Davis TP, Ke PC (2015) DNA Melting and Genotoxicity Induced by Silver Nanoparticles and Graphene. Chem Res Toxicol 28:1023-1035. doi:10.1021/acs.chemrestox.5b00052

Jaffal A, Betoulle S, Biagianti-Risbourg S, Terreau A, Sanchez W, Paris-Palacios S (2015) Heavy metal contamination and hepatic toxicological responses in brown trout (Salmo trutta) from the Kerguelen Islands. Polar Res. doi:10.3402/polar.v34.22784

Janaina R, Sérgio MM, Quinzani JB (2005) Comet assay comparison of different Corbicula fluminea (Mollusca) tissues for the detection of genotoxicity. Genet Mol Biol 28:464-468. doi:10. 1590/s1415-47572005000300023

Jollow DJ, Mitchell JR, Zampaglione N, Gillette JR (1974) Bromobenzene-Induced Liver Necrosis. Protective Role of Glutathione and Evidence for 3,4-Bromobenzene Oxide as the Hepatotoxic Metabolite. Pharmacology 11(3):151-169

Jovanović B, Anastasova L, Rowe EW, Zhang Y, Clapp AR, Palić D (2011) Effects of nanosized titanium dioxide on innate immune system of fathead minnow (Pimephales promelas Rafinesque, 1820). Ecotoxicol Environ Saf 74:675-683. doi:10.1016/j. ecoenv.2010.10.017 
Kanipandian N, Thirumurugan R (2014) A feasible approach to phyto-mediated synthesis of silver nanoparticles using industrial crop Gossypium hirsutum (cotton) extract as stabilizing agent and assessment of its in vitro biomedical potential. Ind Crops Prod 55:1-10. doi:10.1016/j.indcrop.2014.01.042

Karlsson HL (2010) The comet assay in nanotoxicology research. Anal Bioanal Chem 398:651-666. doi:10.1007/s00216-0103977-0

Karlsson HL, Di Bucchianico S, Collins AR, Dusinska M (2015) Can the comet assay be used reliably to detect nanoparticle-induced genotoxicity? Environ Mol Mutagen 56:82-96. doi:10.1002/em. 21933

Kataria N, Kataria AK, Pandey N, Gupta P (2010) Serum biomarkers of physiological defense against reactive oxygen species during environmental stress in Indian dromedaries. HVM Bioflux 2:55-60

Khan MS, Jabeen F, Asghar MS, Qureshi NA, Shakeel M, Noureen A, Shabbir S (2015a) Role of nao-ceria in the amelioration of oxidative stress: current and future applications in medicine Int. J Biosci 6:89-109. doi:10.12692/ijb/6.8.89-109

Khan MS, Jabeen F, Qureshi NA, Asghar MS, Shakeel M, Noureen A (2015b) Toxicity of silver nanoparticles in fish: a critical review. J Bio Environ Sci 6:211-227

Khan MS, Qureshi NA, Jabeen F, Asghar MS, Shakeel M, Fakhar -e Alam M (2016) Eco-Friendly Synthesis of Silver Nanoparticles Through Economical Methods and Assessment of Toxicity Through Oxidative Stress Analysis in the Labeo Rohita Biol Trace Elem Res:1-13 doi:10.1007/s12011-016-0838-5

Kovvuru P, Mancilla PE, Shirode AB, Murray TM, Begley TJ, Reliene R (2015) Oral ingestion of silver nanoparticles induces genomic instability and DNA damage in multiple tissues. Nanotoxicoloy 9:162-171. doi:10.3109/17435390.2014.902520

Kumar A, Joshi H, Pasricha R, Mandale A, Sastry M (2003) Phase transfer of silver nanoparticles from aqueous to organic solutions using fatty amine molecules. $\mathrm{J}$ Colloid Interface Sci 264:396-401

Levard C, Hotze EM, Lowry GV, Brown GE (2012) Environmental transformations of silver nanoparticles: impact on stability and toxicity. Environ Sci Technol 46:6900-6914. doi:10.1021/ es2037405

Luoma SN, Rainbow PS, Luoma S (2008) Metal contamination in aquatic environments: science and lateral management. Cambridge Univ Press. doi:10.1111/j.1095-8649.2009.02440_4.x

Maurer L, Meyer J (2016) A systematic review of evidence for silver nanoparticle-induced mitochondrial toxicity Environ Sci. NANO $3: 311-322$

Monfared AL, Soltani S (2013) Effects of silver nanoparticles administration on the liver of rainbow trout (Oncorhynchus mykiss): histological and biochemical studies. Eur J Exp Biol 3:285-289

Nel A, Xia T, Mädler L, Li N (2006) Toxic potential of materials at the nanolevel. Science 311:622-627. doi:10.1126/science. 1114397

Pal A, Shah S, Devi S (2007) Synthesis of Au, Ag and Au-Ag alloy nanoparticles in aqueous polymer solution. Colloids Surf A Physicochem Eng Asp 302:51-57

Palhares D, Grisolia CK (2002) Comparison between the micronucleus frequencies of kidney and gill erythrocytes in tilapia fish, following mitomycin C treatment. Genet Mol Biol 25:281-284. doi:10.1590/s1415-47572002000300005

Paulraj P, Janaki N, Sandhya S, Pandian K (2011) Single pot synthesis of polyaniline protected silver nanoparticles by interfacial polymerization and study its application on electrochemical oxidation of hydrazine. Colloids Surf A Physicochem Eng Asp 377:28-34. doi:10.1016/j.colsurfa.2010.12.001

Pfurtscheller K, Petnehazy T, Goessler W, Bubalo V, Kamolz LP, Trop M (2014) Transdermal uptake and organ distribution of silver from two different wound dressings in rats after a burn trauma. Wound Repair Regen 22:654-659

Rajkumar K, Kanipandian N, Thirumurugan R (2015) Toxicity assessment on haemotology, biochemical and histopathological alterations of silver nanoparticles-exposed freshwater fish Labeo rohita. Appl Nanosci 1-11 doi:10.1007/s13204-015-0417-7

Reddy TK, Reddy SJ, Prasad T (2013) Effect of silver nanoparticles on energy metabolism in selected tissues of Aeromonas hydrophila infected Indian major. Carp Catla catla IOSR J Pharm 3:49-55. doi:10.9790/3013-31204955

Rocha C, Cavalcanti B, Pessoa CO, Cunha L, Pinheiro RH, Bahia M, Ribeiro H, Cestari M, Burbano R (2011) Comet assay and micronucleus test in circulating erythrocytes of Aequidens tetramerus exposed to methylmercury. In vivo 25:929-933

Simonian N, Coyle J (1996) Oxidative stress in neurodegenerative diseases. Annu Rev Pharmacol Toxicol 36:83-106. doi:10.1146/ annurev.pa.36.040196.000503

Singn N, Mccoy M, Tice R, Schneider E (1988) A simple technique for quantification of low levels of DNA damage in individual cells. Exp Cell Res 175:184-191. doi:10.1016/00144827(88)90265-0

Smith IC, Carson BL (1977) Trace metals in the environment vol 1. Arbor Science Publishers USA

Sohn EK, Johari SA, Kim TG, Kim JK, Kim E, Lee JH, Chung YS, Yu IJ (2015) Aquatic Toxicity Comparison of Silver Nanoparticles and Silver Nanowires Biomed Res Int:1-16 doi:10.1155/ 2015/893049

Taju G, Majeed SA, Nambi K, Hameed AS (2014) In vitro assay for the toxicity of silver nanoparticles using heart and gill cell lines of Catla catla and gill cell line of Labeo rohita. Comp Biochem Physiol C Pharmacol Toxicol 161:41-52. doi:10.1016/j.cbpc. 2014.01.007

Tran QH, Le A-T (2013) Silver nanoparticles: synthesis, properties, toxicology, applications and perspectives. Adv Neural Sci Nanosci Nanotech 4:033001 doi:10.1088/2043-6262/4/3/033001

Vance ME, Kuiken T, Vejerano EP, McGinnis SP, Hochella MF Jr, Rejeski D, Hull MS (2015) Nanotechnology in the real world: Redeveloping the nanomaterial consumer products inventory. Beilstein J Nanotechnol 6:1769-1780. doi:10.3762/bjnano.6.181

Vignesh V, Anbarasi KF, Karthikeyeni S, Sathiyanarayanan G, Subramanian P, Thirumurugan R (2013) A superficial phytoassisted synthesis of silver nanoparticles and their assessment on hematological and biochemical parameters in Labeo rohita (Hamilton, 1822). Colloids Surf A Physicochem Eng Asp 439:184-192. doi:10.1016/j.colsurfa.2013.04.011

Wijnhoven SW, Peijnenburg WJ, Herberts CA, Hagens WI, Oomen AG, Heugens EH, Roszek B, Bisschops J, Gosens I, Van De Meent D (2009) Nano-silver-a review of available data and knowledge gaps in human and environmental risk assessment. Nanotoxicology 3:109-138 doi:10.1080/17435390902725914

Wilchek M, Bayer EA (1990) Introduction to avidin-biotin technology. Methods Enzymol 184:5-13

Woodrow Wilson d (2016) Nanotechnology consumer product inventory http://www.nanotechproject.org/cpi/about/analysis. Accessed 28 April 2016 